\title{
Trend Analyses of Critical Values Obtained for Overall Node Energy Savings Achievable in Ubicomp MANETs Using Location-Aware Transmission.
}

\author{
M. Kaleem GALAMALI, Assoc. Prof Nawaz MOHAMUDALLY
}

\begin{abstract}
Two promising avenues in the field of ubicomp are MANET transmission strategies and location-aware transmission [1-46]. The merging of these two fields is bound to lead to betterment in ubicomp and justifies the amounts of research involved. One factor, over which success of these strategies depend, is correct protocols designs. Current research attempts are claimed to be unsuitable for "correct the first time implementations" [84] because present methods for protocol design are heuristic in nature. Middleware services and applications are also subject to optimisation methods [85]. Novel network architecture for ubicomp is also felt needed to suit QoS and adaptability to node densities [86]. A longer term objective in this direction is to achieve realism in design and evaluation of wireless routing protocols [87]. Such direction of research will also entail more precise features for predictability in ubicomp. Achieving realism is a tedious process since it involves realism in every aspect related to ubicomp. One such aspect was studied in a previous research [15] to assess the trend of energy savings achievable by overall nodes (OES) in locationaware MANET transmission, followed by the study of trends for each OES parameter of equations [31].
\end{abstract}

To upgrade realism in knowledge of these trends, in this paper, the successive questions is put forward as: "What are the observable critical values in OES trends? What are the trends of variation observable within each critical value for metric OES over varying node densities?"

Such knowledge will indeed aid designers in developing more realistic ubicomp scenarios over which new ubicomp features and protocols can be tested more realistically. This work follows-up from previous work [1-46].

Key terms: Ubicomp- Ubiquitous Computing, MAUCMobile and Ubiquitous Computing, ES- Energy Savings, OES- Overall ES, MANET- Mobile Adhoc Network, CBR- Constant Bit Rate, CV- Critical Value.

M. Kaleem GALAMALI,

University of Technology Mauritius (student)

Mauritius

Assoc. Prof Nawaz Mohamudally

University of Technology Mauritius,

Mauritius

\section{Introduction}

Many factors [2] affect energy consumption in MAUC, among which type of transmission and node density remain significant ones. In a previous work [15], an attempt was made through simulation experiments, to find a particular trend/model which depicts energy savings that can be reached by overall nodes in MAUC (OES) to rate the effectiveness of location-aware MANET transmission strategies compared to the theoretical/empirical models derived in simulations. The model put forward for the metric OES was the normal distribution model of form:

$F(x)=b *(1 /(a * \operatorname{sqrt}(2 * p i))) * \exp \left(-(x-c)^{2} / 2 * a * a\right)$

The study which followed [31] was mathematical modelling of the trends of the three parameters of equation obtained. It was stated that [31] such knowledge will help designers to better understand evolution and predictability of ubicomp environments. To assist in such aspect, a platform of realistic simulation scenarios over which testings of newly developed components, including communication protocols, can be undertaken conveniently.

The next level of research that is required for the metric OES is identifying certain key critical values obtained during experimentations and formulating the corresponding mathematical trend of variations over varying node densities for each critical value. Eleven such critical values have been obtained.

The key contribution of this paper is the establishment of the trend of variation covering node numbers 7 until 56 , for each of the eleven critical values observed for metric OES introduced in previous papers [15, 31]. Availability of such data will certainly help ubicomp designers to better understand the evolution and predictability of ubicomp behaviour and derive more authentic simulation scenarios over which novel communication protocols being designed could be validly tested. The rest of this paper is organised as follows: section 2- OES Critical Values, section 3Critical Values Trend Analyses- Metric OES, section 4Conclusion and References.

\section{OES Critical Values.}

\subsection{Critical Values Identified.}

Eleven critical values have been identified as follows: Column headings are: $\mathrm{C} 1 \rightarrow$ OES Critical Value, $\mathrm{C} 2 \rightarrow$ 
Proc. of the Seventh International Conference On Advances in Computing, Electronics and Electrical Technology - CEET 2017. Copyright (C) Institute of Research Engineers and Doctors. All rights reserved. ISBN: 978-1-63248-126-9 doi: 10.15224/ 978-1-63248-126-9-20

Meaning of OES Critical Value, $\mathrm{C} 3 \rightarrow$ Corresponding figure number for the OES Critical Value.

\begin{tabular}{|c|l|c|}
\hline C1 & C2 & C3 \\
\hline 1 & Smallest value of OES noted. & 1 \\
\hline 3 & \%CBR at smallest value of OES. & 2 \\
\hline 4 & Highest value of OES noted. & 3 \\
\hline 5 & \%CBR at highest value of OES. & 4 \\
\hline 6 & $\%$ CBR at negative value of OES. & 5 \\
\hline 7 & \%CBR at OES value of 0. & 6 \\
\hline 8 & \%CBR at modal value of OES. & 8 \\
\hline 9 & \%CBR with OES value below & 9 \\
\hline 10 & modal value \\
\hline 11 & \% & 9 CBR with OES value as from \\
\hline
\end{tabular}

Table 1: OES Critical Values

\subsection{Experimental Critical Values Obtained.}

The values obtained in experiments are summarised below. Values have been rounded to a maximum of 9 decimal places. Column heading NN $\rightarrow$ Node Number.

\begin{tabular}{|c|c:c|c:c|c|}
\hline NN & CV1 & CV2 & CV3 & CV4 & CV5 \\
\hline 7 & -1392 & 0.07936507 & 90 & 0.079365079 & 11.666666667 \\
\hline 8 & -1392 & 0.07959248 & 90 & 0.079365079 & 11.668258516 \\
\hline 9 & -1183 & 0.07936507 & 88 & 0.174603175 & 12.380952381 \\
\hline 10 & -1203 & 0.07936507 & 89 & 0.079365079 & 13.968253968 \\
\hline 11 & -1171 & 0.07936507 & 88 & 0.158730159 & 14.682539683 \\
\hline 12 & -1203 & 0.07936507 & 88 & 0.079491256 & 15.739268680 \\
\hline 13 & -1218 & 0.01587301 & 86 & 0.158730159 & 16.031746032 \\
\hline 14 & -1288 & 0.03174603 & 86 & 0.158730159 & 16.428571429 \\
\hline 15 & -1683 & 0.04761904 & 86 & 0.079365079 & 17.380952381 \\
\hline 16 & -2314 & 0.01587301 & 86 & 0.079365079 & 17.460317460 \\
\hline 17 & -3549 & 0.01587301 & 87 & 0.079365079 & 18.571428571 \\
\hline 18 & -4358 & 0.01587301 & 86 & 0.079365079 & 19.761904762 \\
\hline 19 & -3904 & 0.01587301 & 86 & 0.079365079 & 19.523809524 \\
\hline 20 & -4015 & 0.01587301 & 87 & 0.079365079 & 19.285714286 \\
\hline 21 & -1784 & 0.01587301 & 85 & 0.079365079 & 19.761904762 \\
\hline 22 & -2878 & 0.01587301 & 85 & 0.079365079 & 19.761904762 \\
\hline 23 & -3818 & 0.01587301 & 85 & 0.158730159 & 20.238095238 \\
\hline 24 & -3147 & 0.01587301 & 85 & 0.158730159 & 19.920634921 \\
\hline 25 & -2276 & 0.01587301 & 85 & 0.079365079 & 20.079365079 \\
\hline 26 & -3228 & 0.01587301 & 83 & 0.158730159 & 21.190476190 \\
\hline 27 & -3210 & 0.01587301 & 83 & 0.158730159 & 20.968253968 \\
\hline 28 & -3128 & 0.01587301 & 82 & 0.079365079 & 21.825396825 \\
\hline 29 & -3178 & 0.01587301 & 83 & 0.079365079 & 22.063492063 \\
\hline 30 & -3223 & 0.01587301 & 81 & 0.238095238 & 22.777777778 \\
\hline 31 & -1628 & 0.01587301 & 84 & 0.079365079 & 21.349206349 \\
\hline 32 & -1673 & 0.01587301 & 84 & 0.079365079 & 21.904761905 \\
\hline 33 & -1679 & 0.01587301 & 84 & 0.079365079 & 22.2222222222 \\
\hline 34 & -1684 & 0.01587301 & 83 & 0.079365079 & 22.539682540 \\
\hline 35 & -1701 & 0.01587301 & 83 & 0.079365079 & 22.619047619 \\
\hline 36 & -1771 & 0.01587301 & 81 & 0.079365079 & 23.253968254 \\
\hline 37 & -1593 & 0.03175107 & 82 & 0.158755358 & 23.495792983 \\
\hline 38 & -1693 & 0.03175107 & 82 & 0.158755358 & 23.650793651 \\
\hline 39 & -1716 & 0.03175107 & 83 & 0.079365079 & 24.285714286 \\
\hline 40 & -1614 & 0.03175107 & 82 & 0.158730159 & 24.206349206 \\
\hline 41 & -1590 & 0.07936507 & 82 & 0.158730159 & 24.365079365 \\
\hline & & & & & \\
\hline
\end{tabular}

\begin{tabular}{|l|l|l|l|l|l|}
\hline 42 & -1933 & 0.06349206 & 82 & 0.079365079 & 23.968253968 \\
\hline 43 & -1506 & 0.07936507 & 83 & 0.079365079 & 24.523809524 \\
\hline 44 & -1483 & 0.03176620 & 82 & 0.158831004 & 24.205844981 \\
\hline 45 & -1659 & 0.01587301 & 83 & 0.079365079 & 24.285714286 \\
\hline 46 & -1520 & 0.07936507 & 83 & 0.079365079 & 24.603174603 \\
\hline 47 & -1520 & 0.07936507 & 83 & 0.079365079 & 24.206349206 \\
\hline 48 & -2501 & 0.07936507 & 84 & 0.079365079 & 24.682539683 \\
\hline 49 & -2421 & 0.07936507 & 83 & 0.079365079 & 25.158730159 \\
\hline 50 & -3138 & 0.01587301 & 81 & 0.079365079 & 25.174603175 \\
\hline 51 & -3458 & 0.01587301 & 81 & 0.079365079 & 25.634920635 \\
\hline 52 & -4908 & 0.01587301 & 81 & 0.079365079 & 26.1111111111 \\
\hline 53 & -4915 & 0.01587301 & 81 & 0.079365079 & 26.190476190 \\
\hline 54 & -5715 & 0.01587301 & 81 & 0.079365079 & 25.873015873 \\
\hline 55 & -5683 & 0.01587301 & 82 & 0.079365079 & 26.190476190 \\
\hline 56 & -5101 & 0.01587301 & 81 & 0.079365079 & 25.634920635 \\
\hline
\end{tabular}

Table 2a: Experimental Critical Values Obtained(1)

\begin{tabular}{|c|c|c|c|c|}
\hline $\mathrm{NN}$ & CV6 & CV7 & CV8 & CV9 \\
\hline 7 & 0.07936507 & 88.25396825 & 2.69841269 & 73.01587301 \\
\hline 8 & 0.07959248 & 88.25214899 & 2.76981852 & 72.95447309 \\
\hline 9 & 0.23809523 & 87.38095238 & 2.61904761 & 66.96825396 \\
\hline 10 & 0.07936507 & 85.95238095 & 2.28571428 & 66.76190476 \\
\hline 11 & 0.07936507 & 85.23809523 & 2.41269841 & 76.55555555 \\
\hline 12 & 0.07949125 & 84.18124006 & 2.46422893 & 61.84419713 \\
\hline 13 & 0.31746031 & 84.04761904 & 2.25396825 & 61.11111111 \\
\hline 14 & 0.31746031 & 83.25396825 & 2.15873015 & 55.47619047 \\
\hline 15 & 0.23809523 & 82.38095238 & 3.00000000 & 68.17460317 \\
\hline 16 & 0.39682539 & 82.38095238 & 2.30158730 & 82.6 \\
\hline 17 & 0.52380952 & 80.90476190 & 2.19047619 & 50.98412698 \\
\hline 18 & 0.53968254 & 79.69841269 & 2.69841269 & 75.15873015 \\
\hline 19 & 0.23809523 & 80.23809523 & 44444 & 14285 \\
\hline 20 & 0.23809523 & 80.47619047 & 2.22222222 & 72.06349206 \\
\hline 21 & 0.47619047 & 76 & 2222222 & \\
\hline 22 & 0.39682539 & 79.84126984 & 2.38095238 & 65. \\
\hline 23 & 0.23809523 & 380952 & 5238 & 6984 \\
\hline 24 & 0.23809523 & 79.84126984 & 2.30158730 & 76.66666666 \\
\hline 25 & 0.23809523 & 79.68253968 & 2.36507936 & 63.66666666 \\
\hline 26 & 0.39682539 & 78.41269841 & 2.06349206 & 44.20634920 \\
\hline 27 & 0.30158730 & 78.73015873 & 2.25396825 & 61.63492063 \\
\hline 28 & 0.31746031 & 77.85714285 & 2.93650793 & 76.26984127 \\
\hline 29 & 0.31746031 & 4761 & & \\
\hline 30 & 0.07936507 & 77.14285714 & 2.25396825 & 69.92063492 \\
\hline 31 & 0.71428571 & 77.93650793 & 2.22222222 & 78.01587301 \\
\hline 32 & 0.66666666 & 77.42857142 & 2.30158730 & 73.17460317 \\
\hline 33 & 1.00000000 & 76.77777777 & 2.30158730 & 72.14285714 \\
\hline 34 & 0.4761 & 76.98412698 & 2.26984127 & 80.87301587 \\
\hline 35 & 0.79365079 & 76.58730158 & 2.19047619 & 73.17460317 \\
\hline 36 & 0.63492063 & 76.11111111 & 2.30158730 & 7301 \\
\hline 37 & 0.44451500 & 76.05969201 & 2.38133037 & 71.18590252 \\
\hline 38 & 0.39682539 & 75.95238095 & 2.36507936 & 80.49206349 \\
\hline 39 & 0.31746031 & 75.39682539 & 2.30158730 & 66.50793650 \\
\hline 40 & 0.55555555 & 75.23809523 & 2.20634920 & 67.07936507 \\
\hline 41 & 0.42857142 & 75.20634920 & 2.68253968 & 67.38095238 \\
\hline 42 & 0.31746031 & 75.71428571 & 2.25396825 & 72.74603174 \\
\hline 43 & 0.15873015 & 75.31746031 & 2.69841269 & 64.28571428 \\
\hline 44 & 0.23824650 & 75.55590851 & 2.54129606 & 56.73443456 \\
\hline 45 & 0.39682539 & 75.31746031 & 2.22222222 & 57.69841269 \\
\hline 46 & 0.15873015 & 75.23809523 & 2.22222222 & 65.55555555 \\
\hline 47 & 0.39682539 & 75.39682539 & 1.98412698 & 78.01587301 \\
\hline
\end{tabular}


Proc. of the Seventh International Conference On Advances in Computing, Electronics and Electrical Technology - CEET 2017. Copyright (C) Institute of Research Engineers and Doctors. All rights reserved.

ISBN: 978-1-63248-126-9 doi: 10.15224/ 978-1-63248-126-9-20

\begin{tabular}{|c|c|c|c|c|c|}
\hline 48 & 0.41269841 & 74.90476190 & 2.06349206 & 63.09523809 \\
\hline 49 & 0.39682539 & 74.44444444 & 2.00000000 & 70.14285714 \\
\hline 50 & 0.55555555 & 74.26984127 & 2.06349206 & 70.79365079 \\
\hline 51 & 0.47619047 & 73.88888888 & 2.61904761 & 69.04761904 \\
\hline 52 & 0.39682539 & 73.49206349 & 2.04761904 & 66.03174603 \\
\hline 53 & 0.31746031 & 73.49206349 & 2.12698412 & 71.96825396 \\
\hline 54 & 0.31746031 & 73.80952381 & 2.14285714 & 66.11111111 \\
\hline 55 & 0.15873015 & 73.65079365 & 2.49206349 & 66.34920634 \\
\hline 56 & 0.50793650 & 73.85714285 & 2.26984127 & 68.44444444 \\
\hline
\end{tabular}

Table 2b: Experimental Critical Values Obtained(2)

\begin{tabular}{|c|c|c|}
\hline $\mathrm{NN}$ & CV10 & CV11 \\
\hline 7 & -68 & 11.190476190 \\
\hline 8 & -69 & 11.190703598 \\
\hline 9 & -79 & 11.825396825 \\
\hline 10 & -98 & 13.253968254 \\
\hline 11 & -112 & 13.968253968 \\
\hline 12 & -126 & 14.864864865 \\
\hline 13 & -122 & 15.079365079 \\
\hline 14 & -130 & 15.555555556 \\
\hline 15 & -142 & 16.507936508 \\
\hline 16 & -139 & 16.587301587 \\
\hline 17 & -147 & 17.539682540 \\
\hline 18 & -151 & 18.888888889 \\
\hline 19 & -159 & 18.571428571 \\
\hline 20 & -163 & 18.095238095 \\
\hline 21 & -178 & 18.809523810 \\
\hline 22 & -176 & 18.492063492 \\
\hline 23 & -183 & 18.809523810 \\
\hline 24 & -205 & 18.571428571 \\
\hline 25 & -184 & 18.571428571 \\
\hline 26 & -230 & 19.365079365 \\
\hline 27 & -230 & 19.301587302 \\
\hline 28 & -232 & 20.158730159 \\
\hline 29 & -227 & 20.253968254 \\
\hline 30 & -231 & 21.111111111 \\
\hline 31 & -200 & 19.841269841 \\
\hline 32 & -198 & 20.158730159 \\
\hline 33 & -213 & 20.238095238 \\
\hline 34 & -207 & 20.634920635 \\
\hline 35 & -213 & 20.730158730 \\
\hline 36 & -249 & 21.587301587 \\
\hline 37 & -238 & 21.511351008 \\
\hline 38 & -240 & 21.746031746 \\
\hline 39 & -242 & 22.460317460 \\
\hline 40 & -257 & 22.460317460 \\
\hline 41 & -262 & 22.619047619 \\
\hline 42 & -249 & 22.539682540 \\
\hline 43 & -241 & 23.095238095 \\
\hline 44 & -238 & 22.538119441 \\
\hline 45 & -236 & 22.619047619 \\
\hline 46 & -234 & 23.095238095 \\
\hline 47 & -243 & 22.698412698 \\
\hline 48 & -252 & 23.253968254 \\
\hline 49 & -257 & 23.492063492 \\
\hline 50 & -218 & 23.666666667 \\
\hline 51 & -225 & 23.809523810 \\
\hline 52 & -221 & 24.126984127 \\
\hline 53 & -227 & 24.047619048 \\
\hline
\end{tabular}

\begin{tabular}{|c|c|c|c}
\hline 54 & -243 & 23.888888889 \\
\hline 55 & -238 & 24.206349206 \\
\hline 56 & -240 & 23.809523810 \\
\hline
\end{tabular}

Table 2c: Experimental Critical Values Obtained(3)

\section{Critical Values Trend Analyses- Metric OES.}

\subsection{General Procedure Adopted.}

The tabulated data for each $\mathrm{CV}$ for metric OES is plotted onto gnuplot over Linux. Graphical analysis using smooth bezier support and "Fit" command is performed. General observations, for each such graph obtained is reported. Several equations of fit have been tried and a summary is reported for each OES critical value. Ultimately, for CV2 and CV4, choice is based on flat values and for other CVs, choice is based on value of least reduced chi-square and secondly on most plausible extendability produced at node numbers 80 , 100 and 120. Finally, the values of parameters for each equation of each OES critical value is also noted.

\subsection{Trend Analysis - OES CV1.}

The curve obtained here appears oscillating along a mildly decreasing straight line.

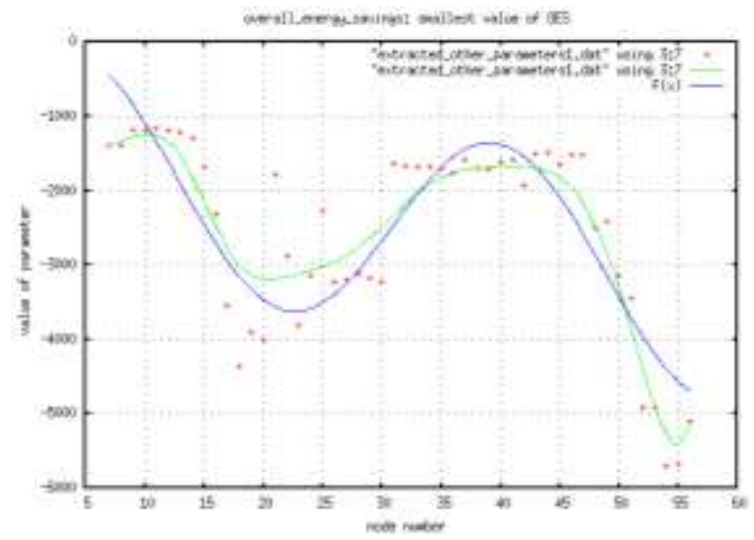

Figure 1: OES Critical Value 1

After lots of trials, the following equation of best fit is put forward.

$$
\begin{array}{ll}
F(x)=(a * \sin (b *(x-c))+d * x+f \\
\begin{array}{ll}
\text { Ch_sq }=445162 & F(80)=-3112.936568812 \\
F(100)=-5498.980636100 & F(120)=-5361.807649708
\end{array}
\end{array}
$$

The parameters of best fit are:

$$
\mathrm{a}=1425, \mathrm{~b}=0.174897, \mathrm{c}=30.8636, \mathrm{~d}=-34.1142
$$$$
\text { , } f=-1436.32
$$

\subsection{Trend Analysis - OES CV2.}

The plots appear to be taking very discrete values and mostly the following is put forward. 
Proc. of the Seventh International Conference On Advances in Computing, Electronics and Electrical Technology - CEET 2017. Copyright (C) Institute of Research Engineers and Doctors. All rights reserved.

ISBN: 978-1-63248-126-9 doi: 10.15224/ 978-1-63248-126-9-20

$$
F(x)=\left\{\begin{array}{lr}
0.079 & 7 \leq x \leq 15 \\
0.0158 & 16 \leq x \leq 40 \\
0.079 & 41 \leq x \leq 49 \\
0.0158 & x \geq 50
\end{array}\right.
$$

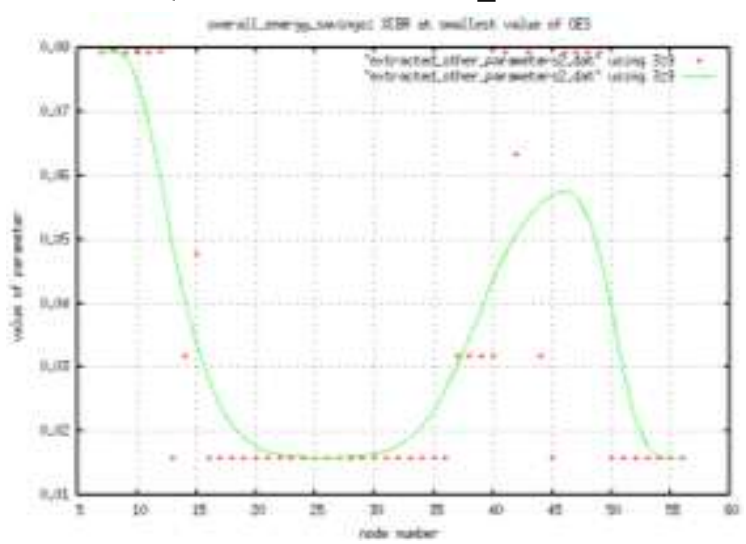

Figure 2: OES Critical Value 2

\subsection{Trend Analysis - OES CV3.}

The curve obtained here mostly depicts a decreasing tendency at a decreasing rate.

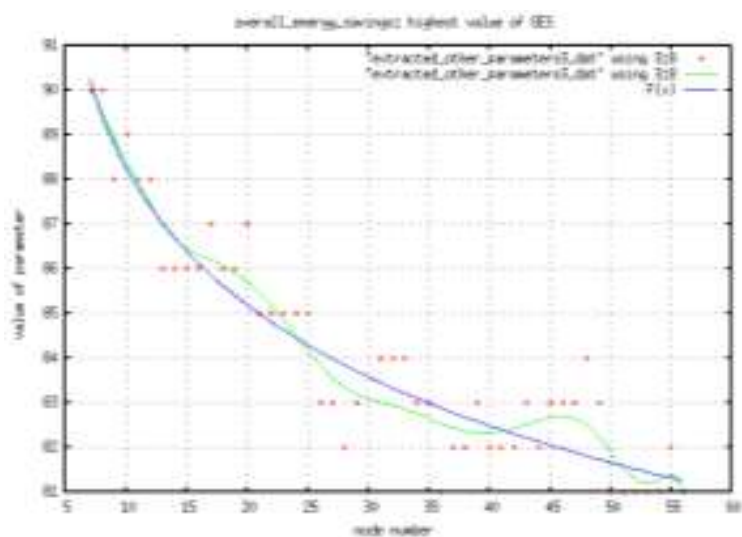

Figure 3: OES Critical Value 3

The potentially applicable equations are:

$$
\begin{aligned}
& \text { 1. } F(x)=a / \log ((b * x)+c) \\
& \text { Ch_sq }=0.904451 \quad \mathrm{~F}(80)=79.673562914 \\
& \mathrm{~F}(100)=78.816374509 \quad \mathrm{~F}(120)=78.127963934
\end{aligned}
$$

2. $F(x)=a / \log \left((b * x)+\left(c * x^{1}\right)\right)$

$$
\begin{array}{ll}
\text { Ch_sq }=0.889077 & \mathrm{~F}(80)=79.867714129 \\
\mathrm{~F}(100)=79.060187887 & \mathrm{~F}(120)=78.412413324
\end{array}
$$

3. $F(x)=a / \log \left((b * x)+\left(c^{*} x-{ }^{1}\right)\right)$

$$
\begin{array}{ll}
\text { Ch_sq }=0.879814 & \mathrm{~F}(80)=79.990451866 \\
\mathrm{~F}(100)=79.221202808 & \mathrm{~F}(120)=78.603996668
\end{array}
$$

4. $F(x)=a / \log \left((b * x)+\left(c^{*} x^{-1.1}\right)\right)$

$$
\begin{array}{ll}
\text { Ch_sq }=0.889333 & \mathrm{~F}(80)=79.867602921 \\
\mathrm{~F}(100)=79.058473598 & \mathrm{~F}(120)=78.409438834
\end{array}
$$

\section{Choice of best fit for OES Critical Value 3}

The equation in part 3 above was selected because of smallest reduced chi-square value obtained and good extendability. The parameters obtained for best fit are: $\mathrm{a}=1841.97, \mathrm{~b}=1.2535\left(\mathrm{e}^{+08}\right), \mathrm{c}=-1.01421\left(\mathrm{e}^{+09}\right)$

\subsection{Trend Analysis - OES CV4.}

Most plots (36 out of 50, i.e. $72 \%$ ) have stabilised at 0.08 . Hence it is put forward with $72 \%$ confidence, that for any node number

$$
F(x)=0.08
$$

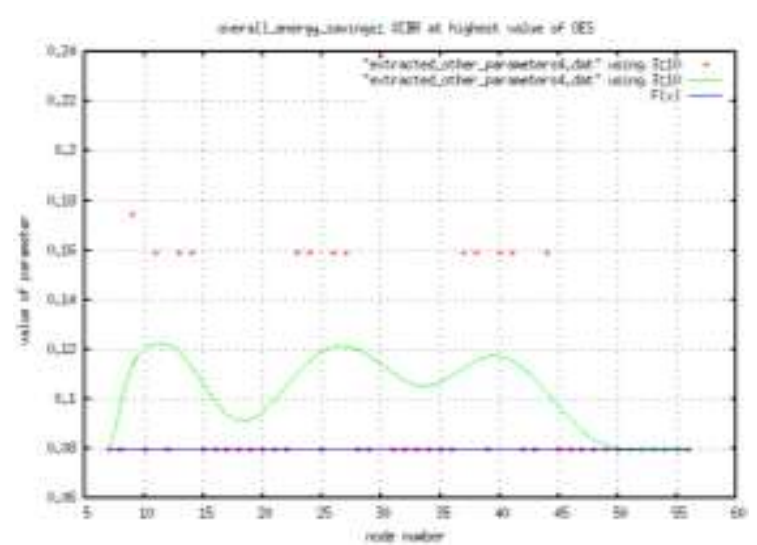

Figure 4: OES Critical Value 4

\subsection{Trend Analysis - OES CV5.}

The curve obtained here tends to increase at a decreasing rate. A minor oscillation of a negligible amplitude is also noted.

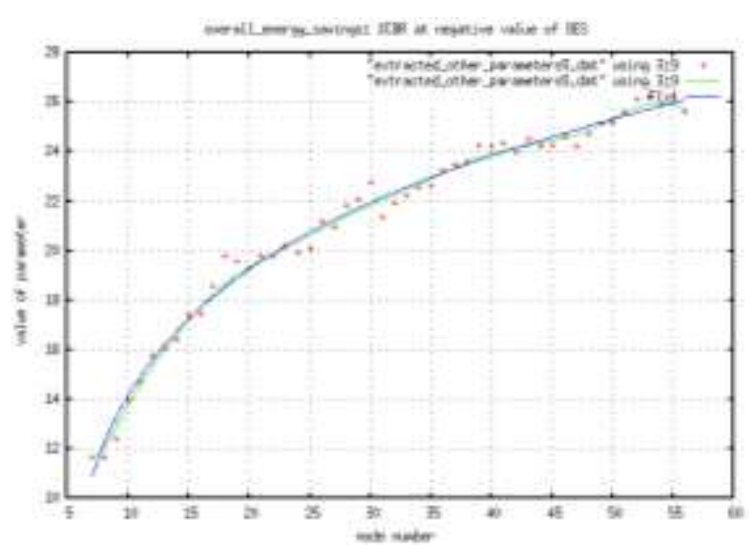

Figure 5: OES Critical Value 5

The potentially applicable equations are:

$$
\begin{aligned}
& \text { 1. } F(x)=a / \log ((b * x)+c)+d \\
& \text { Ch_sq }=0.205587 \\
& \mathrm{~F}(80)=28.256059529 \\
& \mathrm{~F}(100)=29.643572902 \quad \mathrm{~F}(120)=30.770978603 \\
& \text { 2. } F(x)=a / \log ((b * x)+c)+(d * x) \\
& \text { Ch_sq }=0.205873 \\
& \mathrm{~F}(80)=28.174796864 \\
& \mathrm{~F}(100)=29.504343610 \\
& \mathrm{~F}(120)=30.566386182 \\
& \text { 3. } F(x)=a / \log ((b * x)+c)+\left(d * x^{2}\right) \\
& \text { Ch_sq }=0.205418 \\
& \mathrm{~F}(80)=28.404420170 \\
& \mathrm{~F}(100)=29.952966180 \\
& \mathrm{~F}(120)=31.288858391
\end{aligned}
$$


Proc. of the Seventh International Conference On Advances in Computing, Electronics and Electrical Technology - CEET 2017. Copyright (C) Institute of Research Engineers and Doctors. All rights reserved.

ISBN: 978-1-63248-126-9 doi: 10.15224/ 978-1-63248-126-9-20

$$
\begin{aligned}
& \text { Ch_sq }=0.204943 \\
& \mathrm{~F}(80)=28.655500222 \\
& \mathrm{~F}(100)=30.583217972 \quad \mathrm{~F}(120)=32.541433350 \\
& \text { 5. } F(x)=a / \log ((b * x)+c)+\left(d * x^{4}\right) \\
& \text { Ch_sq }=0.20459 \quad \mathrm{~F}(80)=28.971851041 \\
& \mathrm{~F}(100)=31.634856333 \quad \mathrm{~F}(120)=35.118801633 \\
& \text { 6. } F(x)=a / \log ((b * x)+c)+\left(d * x^{4 \cdot 3}\right) \\
& \text { Ch_sq }=0.204506 \quad \mathrm{~F}(80)=29.087856884 \\
& \mathrm{~F}(100)=32.084888421 \quad \mathrm{~F}(120)=36.358262107
\end{aligned}
$$

\section{Choice of best fit for OES Critical Value 5}

The equation in part 6 above has been selected because of smallest reduced chi-square value obtained and good extendability. The parameters obtained for best fit are: $\mathrm{a}=5.85415, \mathrm{~b}=1.56688, \mathrm{c}=-4.55575, \mathrm{~d}=6.70487\left(\mathrm{e}^{-09}\right)$

\subsection{Trend Analysis - OES CV6.}

The plots are very scattered. There is a mild increasing tendency at a decreasing rate.

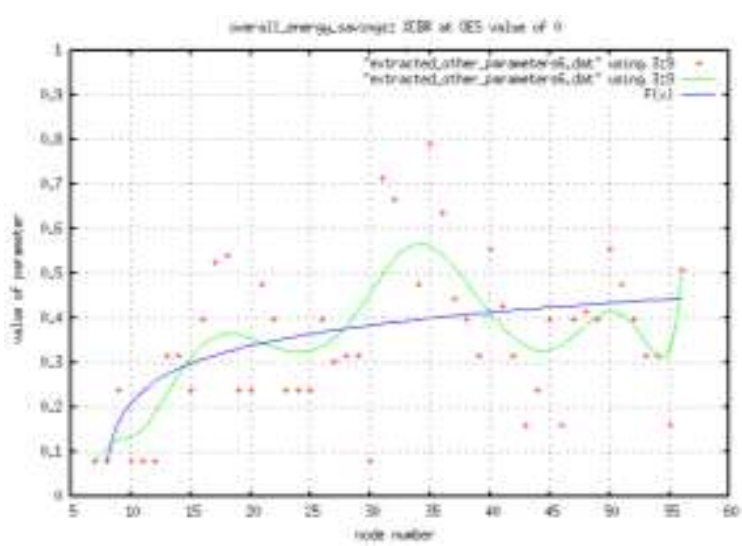

Figure 6: OES Critical Value 6

The potentially applicable equations are:

$1 \cdot F(x)=a * \log (b *(x+c))+d$

$$
\begin{array}{ll}
\text { Ch_sq }=0.0323424 & \mathrm{~F}(80)=0.475864760 \\
\mathrm{~F}(100)=0.494936501 & \mathrm{~F}(120)=0.510257941
\end{array}
$$

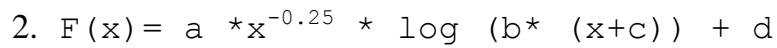

$$
\text { Ch_sq }=0.0295309 \quad \mathrm{~F}(80)=0.140108284
$$$$
\mathrm{F}(100)=-0.035814579 \quad \mathrm{~F}(120)=-0.207996127
$$

3. $F(x)=a * x^{-0.5} * \log (b *(x+c))+d$

$$
\begin{array}{ll}
\text { Ch_sq }=0.0308669 & \mathrm{~F}(80)=0.365214804 \\
\mathrm{~F}(100)=0.338130077 & \mathrm{~F}(120)=0.313691085
\end{array}
$$

4. $F(x)=a * \log (b *(x+c))+\left(d * x^{0.25}\right)$

$$
\begin{array}{ll}
\text { Ch_sq }=0.0294875 & \mathrm{~F}(80)=0.078662802 \\
\mathrm{~F}(100)=-0.167399177 & \mathrm{~F}(120)=-0.425243828
\end{array}
$$

5. $F(x)=a * \log (b *(x+c))+\left(d * x^{0.25}\right)$

$$
\begin{array}{ll}
\text { Ch_sq }=0.0324718 & F(80)=0.469605640 \\
F(100)=0.487130509 & F(120)=0.501248314
\end{array}
$$

\section{Choice of best fit for OES Critical Value 6}

The equation in part 1 above has been selected even if the reduced ch_sq is not smallest, it has good extendability over larger node numbers. The parameters obtained for best fit are: $a=0.078226, b=0.216538$, $c=-7.56063, d=0.260527$

\subsection{Trend Analysis - OES CV7.}

The curve obtained here is mostly decreasing at a decreasing rate.

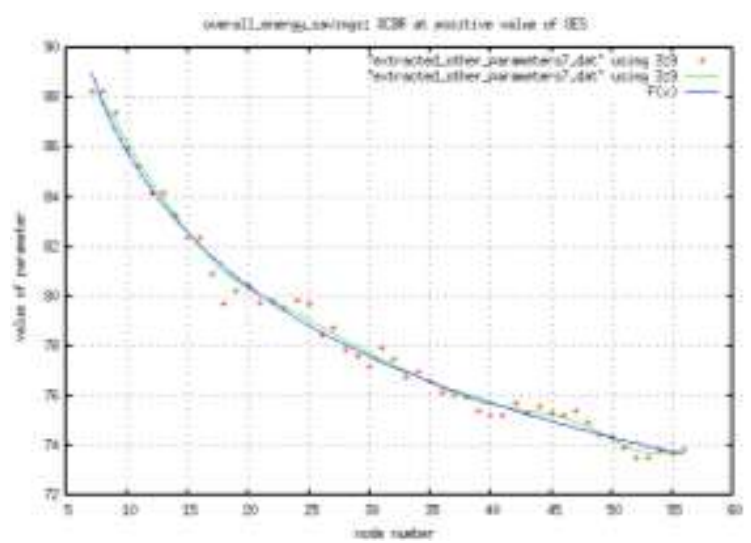

Figure 7: OES Critical Value 7

The potentially applicable equations are:

$$
\begin{aligned}
& \text { 1. } F(x)=a * \exp (b *(x+c))+d \\
& \text { Ch_sq }=0.275267 \quad \mathrm{~F}(80)=73.217928627 \\
& \mathrm{~F}(100)=73.015054317 \quad \mathrm{~F}(120)=72.945424302 \\
& \text { 2. } F(x)=a * x^{0.25} \star \exp (b *(x+c))+d \\
& \text { Ch_sq }=0.35384 \quad \mathrm{~F}(80)=73.733835636 \\
& \mathrm{~F}(100)=73.650798860 \quad \mathrm{~F}(120)=73.631184984 \\
& \text { Ch_sq }=0.208006 \quad \mathrm{~F}(80)=71.561819162 \\
& \mathrm{~F}(100)=70.312027150 \quad \mathrm{~F}(120)=69.313363986 \\
& \text { Ch_sq }=0.273844 \quad \mathrm{~F}(80)=72.496891646 \\
& \mathrm{~F}(100)=71.694909545 \quad \mathrm{~F}(120)=71.128441851
\end{aligned}
$$

\section{Choice of best fit for OES Critical Value 7}

The equation in part 3 above has been selected because of smallest reduced chi-square value obtained and good extendability. The parameters obtained for best fit are:

$a=59.7103, b=-0.000650687, c=12.6124, d=52.7641$

\subsection{Trend Analysis - OES CV8.}

The plots here are very scattered but overall, a decreasing linear tendency is observed.

$$
F(x)=d \star_{x}+f
$$


Proc. of the Seventh International Conference On Advances in Computing, Electronics and Electrical Technology - CEET 2017. Copyright (C) Institute of Research Engineers and Doctors. All rights reserved.

ISBN: 978-1-63248-126-9 doi: 10.15224/ 978-1-63248-126-9-20

$$
\begin{array}{ll}
\text { Ch_sq }=0.0466561 & F(80)=2.064002674 \\
F(100)=1.947457162 & F(120)=1.830911650
\end{array}
$$

The parameters of fit are: $\mathrm{d}=-0.00582728, \mathrm{f}=2.53018$ A tolerance of \pm 0.2 is suggested here.

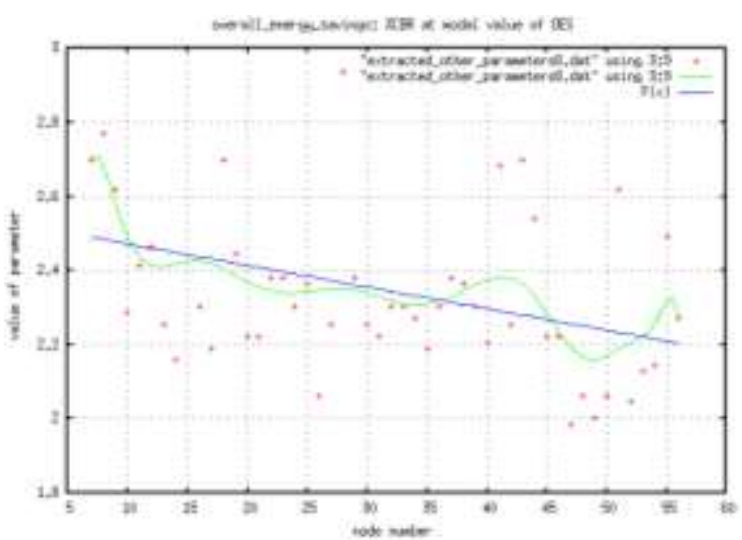

Figure 8: OES Critical Value 8

\subsection{Trend Analysis - OES CV9.}

Though the plots are very scattered, a very mildly increasing linear tendency is observed.

$$
\begin{array}{ll}
F(x)=d * x+f & \\
\text { Ch_sq }=64.2957 & F(80)=69.004150840 \\
F(100)=69.260955073 & F(120)=69.517759305
\end{array}
$$

The parameters of fit are: $\mathrm{d}=0.0128402, \mathrm{f}=67.9769$ A tolerance of \pm 10 is suggested. The projected values vary between 68 and 71 for up to very large node numbers (around 200)

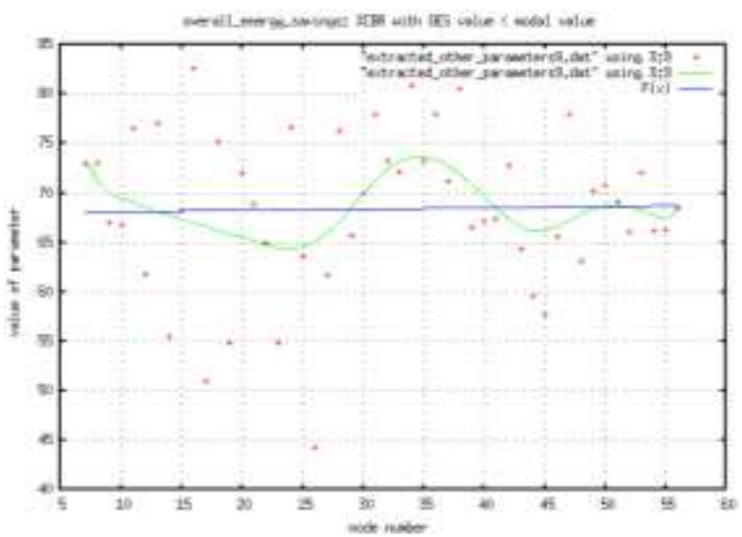

Figure 9: OES Critical Value 9

\subsection{Trend Analysis - OES CV10.}

The curve appears to start decreasing at a decreasing rate until a minimum point is reached and then the curve starts increasing.

The potentially applicable equations are:

$$
\begin{array}{cl}
\text { 1. } F(x)=a * x * \exp & (b *(x+c))+d \\
\text { Ch_sq }=178.664 & F(80)=-194.927203006 \\
F(100)=-151.512380973 & F(120)=-110.122782342
\end{array}
$$

2. $F(x)=a \star x^{2} \star \exp (b *(x+c))+d$

$$
\begin{array}{ll}
\text { Ch_sq }=179.214 & F(80)=-169.255920371 \\
F(100)=-122.859922390 & F(120)=-90.438029622
\end{array}
$$$$
\mathrm{F}(120)=-90.438029622
$$

3. $F(x)=a \star x^{f} \star \exp (b *(x+c))+d$

Ch_sq $=178.269$

$\mathrm{F}(80)=-181.835365125$

$F(100)=-135.304569361$

$F(120)=-96.742935277$

\section{Choice of best fit for OES Critical Value 10}

The equation in part 3 above has been selected because of smallest reduced chi-square value obtained and good extendability. The parameters obtained for best fit are:

$\mathrm{a}=-4.07085, \mathrm{~b}=-0.032515, \mathrm{c}=1.26811, \mathrm{~d}=-$

$14.8437, \mathrm{f}=1.4506$

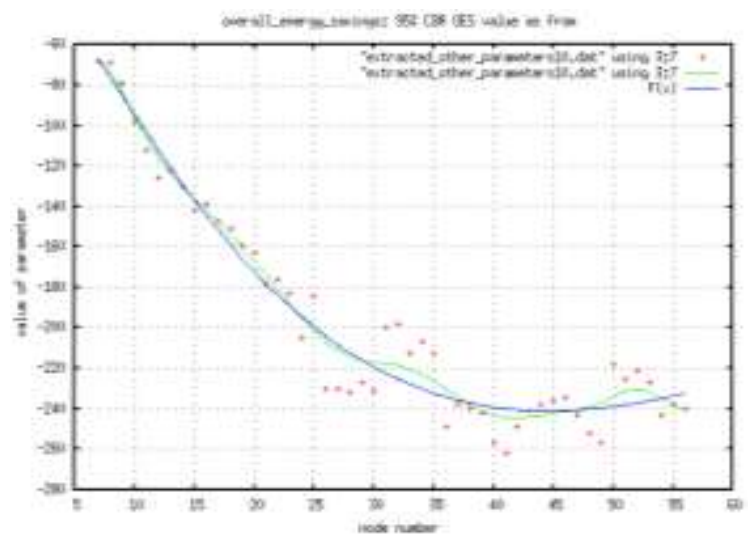

Figure 10: OES Critical Value 10

3.11 Trend Analysis - OES CV11.

Generally, the curve is increasing at a decreasing rate

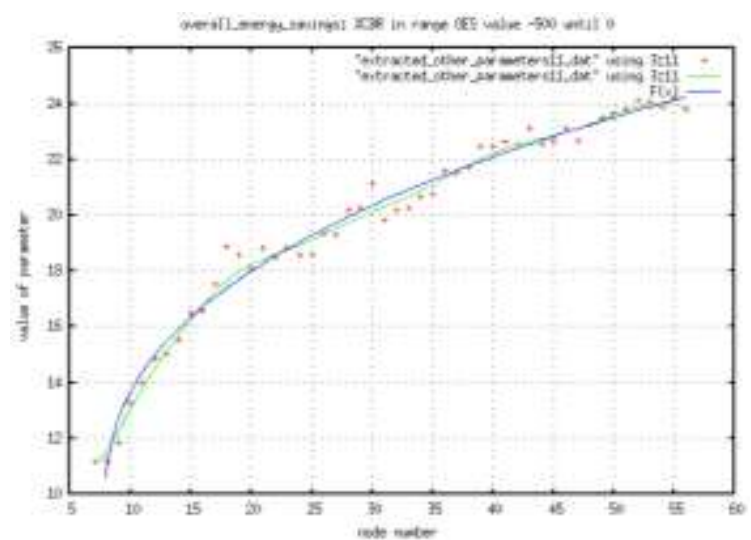

Figure 11: OES Critical Value 11

The potentially applicable equations are:

$$
\begin{aligned}
& \text { 1. } F(x)=a \star \log (b *(x+c))+d \\
& \text { Ch_sq }=0.238574 \quad \mathrm{~F}(80)=26.119749704 \\
& \mathrm{~F}(100)=27.373027788 \quad \mathrm{~F}(120)=28.391669641 \\
& \text { 2. } F(x)=a * x^{0.5} \star \log (b *(x+c))+d \\
& \text { Ch_sq }=0.271233 \quad \mathrm{~F}(80)=27.302091445 \\
& \mathrm{~F}(100)=29.285947469 \quad \mathrm{~F}(120)=31.036674030 \\
& \text { 3. } F(x)=a * x^{0.2} \star \log (b *(x+c))+d \\
& \text { Ch_sq }=0.220172 \quad \mathrm{~F}(80)=26.724775625 \\
& \mathrm{~F}(100)=28.376359605 \quad \mathrm{~F}(120)=29.793119525
\end{aligned}
$$


Proc. of the Seventh International Conference On Advances in Computing, Electronics and Electrical Technology - CEET 2017. Copyright (C) Institute of Research Engineers and Doctors. All rights reserved.

ISBN: 978-1-63248-126-9 doi: 10.15224/ 978-1-63248-126-9-20

$$
\begin{array}{rr}
\text { 4. } F(x)=a * x^{0.15} * \log (b * \quad(x+c))+d \\
\text { Ch_sq }=0.240706 & F(80)=26.301210226 \\
F(100)=27.771408090 & F(120)=29.016300584
\end{array}
$$

\section{Choice of best fit for OES Critical Value 11}

The equation in part 3 above has been selected because of smallest reduced chi-square value obtained and good extendability. The parameters obtained for best fit are:

$$
a=0.966355, b=304.692, c=-7.574, d=3.50619
$$

\section{Conclusion.}

This piece of research was aimed at and has fulfilled the identification of some critical values related to metric OES and their corresponding trends over varying node densities in a MANET topography of 300 $\mathrm{x} 300 \mathrm{~m}^{2}$. The models put forward have involved quite complicated mathematical equations and will assist in studying MANETs for MAUC environment from a software engineering perspective. These mathematical models may be mapped onto programming algorithms, to generate more realistic simulation scenarios for testing newly developed communication protocols and middleware for ubicomp. The experiment was carried out in NS-2 over Linux. The plottings and "fit" attempts were done in gnuplot. For two critical values, best fit was evaluated with flat values and for remaining nine critical values, least reduced chi-square and best extendability of equations at higher node numbers have been used.

Assumptions stated in prior papers [15, 31] hold here also. Gnuplot is also assumed as suitable for this study. The intrinsic constructs of gnuplot is not criticised here.

This work is a follow-up of previous papers [1-13, 15, 31] and dwells as prone to further enhancements. One such further work identified is formulating a method of predictability for metric OES and its trend.

\section{References}

[1] M. Kaleem GALAMALI, Assoc. Prof Nawaz MOHAMUDALLY, Towards Dependable Pervasive Systems-A Position and Vision Paper, CEET 2014

[2] M. Kaleem GALAMALI, Assoc. Prof Nawaz MOHAMUDALLY, Model of Energy Savings achievable with Location-aware Node-to-Node Transmission in UbiComp , CEET 2014

[3] M. Kaleem GALAMALI, Assoc. Prof Nawaz MOHAMUDALLY, Model of Energy Savings achievable with Location-aware Node-to-Node Transmission in UbiComp Using Location Refresh Intervals, CEET 2014

[4] M. Kaleem GALAMALI, Assoc. Prof Nawaz MOHAMUDALLY, Model of Energy Savings achievable with Location-aware Transmission in UbiComp Using Relays, CEET 2014
M. Kaleem GALAMALI, Assoc. Prof Nawaz MOHAMUDALLY, Mathematical modeling of need of exact number of relays to ensure seamless mobility in mobile computing, CEET 2014

6] M. Kaleem GALAMALI, Assoc. Prof Nawaz MOHAMUDALLY, Modelling of need for multiple relays for ensuring seamless mobility, CEET 2014

[7] M. Kaleem GALAMALI, Assoc. Prof Nawaz MOHAMUDALLY, Investigation of prominence of placements of relays in a ubicomp topography,

[8] M. Kaleem GALAMALI, Assoc. Prof Nawaz MOHAMUDALLY, Model of energy savings achievable with location-aware transmission in ubicomp using optimised number of relays.

[9] M. Kaleem GALAMALI, Assoc. Prof Nawaz MOHAMUDALLY, Investigation of Prominence of Placements of Optimised Number of Relays in a Ubicomp Topography using Location-Aware Transmission, CEET 2015.

[10] M. Kaleem GALAMALI, Assoc. Prof Nawaz MOHAMUDALLY, Extending Node Battery Availability in Ubicomp with Location-Aware Transmission, CEET 2015.

[11] M. Kaleem GALAMALI, Assoc. Prof Nawaz MOHAMUDALLY, Extending Node Battery Availability in Ubicomp with Location-Aware Transmission using Location Refresh Intervals, CEET 2015.

[12] M. Kaleem GALAMALI, Assoc. Prof Nawaz MOHAMUDALLY, Extending Node Battery Availability in Ubicomp with Location-Aware Transmission using Uniformly Placed Relays, CEET 2015.

[13] M. Kaleem GALAMALI, Assoc. Prof Nawaz MOHAMUDALLY, Extending Node Battery Availability in Ubicomp with Location-Aware Transmission Using Optimally Placed Relays, CEET 2015.

[14] M. Kaleem GALAMALI, Assoc. Prof Nawaz MOHAMUDALLY, Model of Sender Node Energy Savings Achievable with Location-Aware MANET Transmission in Ubicomp. ACCN 2016

[15] M. Kaleem GALAMALI, Assoc. Prof Nawaz MOHAMUDALLY, Model of Overall Node Energy Savings Achievable with Location-Aware MANET Transmission in Ubicomp. ACCN 2016

[16] M. Kaleem GALAMALI, Assoc. Prof Nawaz MOHAMUDALLY, Model of Sender Node Extra Energy Savings Achievable in MANET Against Direct Node-toNode Transmission Using Location-Aware Transmission in Ubicomp. ACCN 2016

[17] M. Kaleem GALAMALI, Assoc. Prof Nawaz MOHAMUDALLY, Model of Overall Node Extra Energy Savings Achievable in MANET against Direct Node-toNode Transmission Using Location-Aware Transmission in Ubicomp. ACCN 2016

[18] M. Kaleem GALAMALI, Assoc. Prof Nawaz MOHAMUDALLY, Model of Energy Consumption Ratio Achievable in MANET Using Location-Aware Transmission in Ubicomp. ACCN 2016

[19] M. Kaleem GALAMALI, Assoc. Prof Nawaz MOHAMUDALLY, Model of Minimum Energy Consumption Ratio Achievable in MANET Using LocationAware Transmission in Ubicomp. ACCN 2016

[20] M. Kaleem GALAMALI, Assoc. Prof Nawaz MOHAMUDALLY, Model of Maximum Energy Consumption Ratio Achievable in MANET Using LocationAware Transmission in Ubicomp. ACCN 2016

[21] M. Kaleem GALAMALI, Assoc. Prof Nawaz MOHAMUDALLY, Model of Overall Energy Consumption Fairness Ratio Achievable in MANET Using LocationAware Transmission in Ubicomp. ACCN 2016

[22] M. Kaleem GALAMALI, Assoc. Prof Nawaz MOHAMUDALLY, Model of Overall Energy Consumption Fairness Proportion Achievable in MANET Using LocationAware Transmission for Ubicomp, CEET 2016

[23] M. Kaleem GALAMALI, Assoc. Prof Nawaz MOHAMUDALLY, Model of Minimum Fairness Proportion Achievable in MANET Using Location-Aware Transmission for Ubicomp, CEET 2016

[24] M. Kaleem GALAMALI, Assoc. Prof Nawaz MOHAMUDALLY, Model of Maximum Fairness 
Proportion Achievable in MANET Using Location-Aware Transmission for Ubicomp, CEET 2016

[25] M. Kaleem GALAMALI, Assoc. Prof Nawaz MOHAMUDALLY, Model of Sender Fairness Proportion Achievable in MANET Using Location-Aware Transmission for Ubicomp, CEET 2016

[26] M. Kaleem GALAMALI, Assoc. Prof Nawaz MOHAMUDALLY, Model of Distance Travelled by packets in MANETs using Location-Aware Transmission for Ubicomp, CEET 2016

[27] M. Kaleem GALAMALI, Assoc. Prof Nawaz MOHAMUDALLY, Model of Maximum CBR Distance Travelled by packets in MANETs using Location-Aware Transmission for Ubicomp, CEET 2016

[28] M. Kaleem GALAMALI, Assoc. Prof Nawaz MOHAMUDALLY, Model of Minimum CBR Distance Travelled by packets in MANETs using Location-Aware Transmission for Ubicomp, CEET 2016

[29] M. Kaleem GALAMALI, Assoc. Prof Nawaz MOHAMUDALLY, Model of Range CBR Distance Experienced by Transmissions in MANETs using LocationAware Transmission for Ubicomp, CEET 2016

[30] M. Kaleem GALAMALI, Assoc. Prof Nawaz MOHAMUDALLY, Trend Analyses of Parameters of Equations for Sender Node Energy Savings Achievable in ubicomp MANETs using Location-Aware Transmission, ACCN 2017.

[31] M. Kaleem GALAMALI, Assoc. Prof Nawaz MOHAMUDALLY, Trend Analyses of Parameters of Equations for Overall Node Energy Savings Achievable in ubicomp MANETs using Location-Aware Transmission, ACCN 2017.

[32] M. Kaleem GaLAMALI, Assoc. Prof Nawaz MOHAMUDALLY, Trend Analyses of Parameters of Equations for Sender Node Extra Energy Savings Achievable in MANET against Direct Node-to-Node Location-Aware Transmission, ACCN 2017

[33] M. Kaleem GALAMALI, Assoc. Prof Nawaz MOHAMUDALLY, Trend Analyses of Parameters of Equations for Overall Nodes Extra Energy Savings Achievable in MANET against Direct Node-to-Node Location-Aware Transmission, ACCN 2017.

[34] M. Kaleem GALAMALI, Assoc. Prof Nawaz MOHAMUDALLY, Trend Analyses of Parameters of Equations for Energy Consumption Ratio Achievable in Ubicomp MANET Using Location-Aware Transmission, ACCN 2017.

[35] M. Kaleem GALAMALI, Assoc. Prof Nawaz MOHAMUDALLY, Trend Analyses of Parameters of Equations for Minimum Energy Consumption Ratio Achievable in Ubicomp MANETs Using Location-Aware Transmission, ACCN 2017.

[36] M. Kaleem GALAMALI, Assoc. Prof Nawaz MOHAMUDALLY, Trend Analyses of Parameters of Equations for Maximum Energy Consumption Ratio Achievable in Ubicomp MANETs Using Location-Aware Transmission, ACCN 2017.

[37] M. Kaleem GALAMALI, Assoc. Prof Nawaz MOHAMUDALLY, Trend Analyses of Parameters of Equations for Overall Fairness Ratio Achievable in Ubicomp MANETs Using Location-Aware Transmission, ACCN 2017.

[38] M. Kaleem GALAMALI, Assoc. Prof Nawaz MOHAMUDALLY, Trend Analyses of Parameters of Equations for Energy Consumption Fairness Proportion Achievable in Ubicomp MANETs Using Location-Aware Transmission, CEET 2017

[39] M. Kaleem GALAMALI, Assoc. Prof Nawaz MOHAMUDALLY, Trend Analyses of Parameters of Equations for Minimum Fairness Proportion Achievable in Ubicomp MANETs Using Location-Aware Transmission, CEET 2017

[40] M. Kaleem GALAMALI, Assoc. Prof Nawaz MOHAMUDALLY, Trend Analyses of Parameters of Equations for Maximum Fairness Proportion Achievable in Ubicomp MANETs Using Location-Aware Transmission, CEET 2017

[41] M. Kaleem GALAMALI, Assoc. Prof Nawaz MOHAMUDALLY, Trend Analyses of Parameters of Equations for Sender Fairness Proportion Achievable in
Ubicomp MANETs Using Location-Aware Transmission, CEET 2017

[42] M. Kaleem GALAMALI, Assoc. Prof Nawaz MOHAMUDALLY, Trend Analyses of Parameters of Equations for Packets Per Distance Achievable in Ubicomp MANETs Using Location-Aware Transmission, CEET 2017

[43] M. Kaleem GALAMALI, Assoc. Prof Nawaz MOHAMUDALLY, Trend Analyses of Parameters of Equations for Maximum CBR Distance Achievable in Ubicomp MANETs Using Location-Aware Transmission, CEET 2017

[44] M. Kaleem GALAMALI, Assoc. Prof Nawaz MOHAMUDALLY, Trend Analyses of Parameters of Equations for Minimum CBR Distance Achievable in Ubicomp MANETs Using Location-Aware Transmission, CEET 2017

[45] M. Kaleem GALAMALI, Assoc. Prof Nawaz MOHAMUDALLY, Trend Analyses of Parameters of Equations for Range CBR Distance Achievable in Ubicomp MANETs Using Location-Aware Transmission, CEET 2017

[46] M. Kaleem GALAMALI, Assoc. Prof Nawaz MOHAMUDALLY, Trend Analyses of Critical Values Obtained for Sender Node Energy Savings Achievable in Ubicomp MANETs Using Location-Aware Transmission, CEET 2017

[47] Markus Bylund and Zary Segall, Towards seamless mobility with personal servers, 2004

[48] Masugi Inoue, Mikio Hasegawa, Nobuo Ryoki and Hiroyuki Morikawa, Context-Based Seamless Network and Application Control, 2004

[49] Xiang Song, Umakishore Ramachandran, MobiGo: A Middleware for Seamless Mobility, College of Computing Georgia Institute of Technology, Atlanta, GA, USA, August 2007

[50] Budzisz, Ferrús, R., Brunstrom A., Grinnemo, K, Fracchia, R., Galante, G., and Casadevall, F. Towards transport-layer mobility: Evolution of SCTP multihoming, March 2008

[51] Paul Dourish \& Genevieve Bell, Divining a digital future, 2011.

[52] Xiang Song, Seamless Mobility In Ubiquitous Computing Environments, PhD Thesis, Georgia Institute of Technology, August 2008

[53] Kevin O Mahony, Jian Liang, Kieran Delaney, User-Centric Personalization and Autonomous Reconfiguration Across Ubiquitous Computing Environments, NIMBUS Centre Cork Institute of Technology, Cork, Ireland, UBICOMM 2012

[54] Pablo Vidales, Seamless mobility in 4G systems, Technical Report, University of Cambridge, Computer Laboratory, Number 656, November 2005

[55] João Pedro Sousa and David Garlan, Aura: An Architectural Framework for User Mobility in Ubiquitous Computing Environments, School of Computer Science, Carnegie Mellon University, USA, August 2002

[56] Dennis Lupiana, Ciaran O'Driscoll, Fredrick Mtenzi, Defining Smart Space in the Context of Ubiquitous Computing, Dublin Institute of Technology, Ireland, Special Issue on ICIT 2009 Conference - Web and Agent Systems, 2009

[57] N.S.V.Shet1, Prof.K.Chandrasekaran2 and Prof. K.C.Shet3, WAP Based Seamless Roaming In Urban Environment with Wise Handoff Technique, International Journal of UbiComp (IJU), Vol.1, No.4, October 2010

[58] Yipeng Yu Dan He Weidong Hua Shijian Li Yu Qi Yueming Wang Gang Pan, FlyingBuddy2: A Braincontrolled Assistant for the Handicapped, Zhejiang University, UbiComp'12, September 5-8, 2012.

[59] Jing Su, James Scott, Pan Hui, Jon Crowcroft, Eyal de Lara Christophe Diot, Ashvin Goel, Meng How Lim, and Eben Upton, Haggle: Seamless Networking for Mobile Applications, 2007

[60] Rui Han, Moustafa M. Ghanem, Li Guo, Yike Guo*, Michelle Osmond, Enabling cost-aware and adaptive elasticity of multi-tier cloud applications, Future Generation Computer Systems, 2012

[61] Byrav Ramamurthy, K. K. Ramakrishnan , Rakesh K. Sinha, Cost and Reliability Considerations in Designing the NextGeneration IP over WDM Backbone Networks, 2012.

[62] Bhavish Aggarwal, Aditya Akella, Ashok Anand, Athula Balachandran, Pushkar Chitnis, Chitra Muthukrishnan, Ram 
Ramjee and George Varghese, EndRE: An End-System Redundancy Elimination Service for Enterprises, NSDI 2010, San Jose, CA

[63] Ashok Anand, Vyas Sekar and Aditya Akella, SmartRE: An Architecture for Coordinated Network-wide Redundancy Elimination, SIGCOMM 2009, Barcelona, Spain

[64] John Breeden II, "Smart-phone battery life could double without better batteries", Nov 14, 2012

[65] Andy Boxall, "When will your phone battery last as long as your kindle", December 5, 2012.

[66] Imielinski, T. and Navas, J.C. (1999). GPS-based geographic addressing, routing, and resource discovery. Comms. ACM, Vol. 42, No. 4, pp. 86-92.

[67] Hightower, J. and Borriello, G. (2001). Location Systems for Ubiquitous Computing. IEEE Computer, Vol. 34, No. 8, August, pp. 57-66.

[68] Harter, A., Hopper, A., Steggles, P., Ward, A. and Webster, P. (2002). The Anatomy of a Context-Aware Application. Wireless Networks, Vol. 8, No. 2-3, Mar-May, pp. 187-197.

[69] Hightower, J., Brumitt, B. and Borriello, G. (2002). The Location Stack: A Layered Model for Location in Ubiquitous Computing. Proceedings of the 4th IEEE Workshop on Mobile Computing Systems \& Applications (WMCSA 2002), Callicoon, NY, USA, June, pp. 22-28.

[70] Graumann, D., Lara, W., Hightower, J. and Borriello, G. (2003). Real-world implementation of the Location Stack: The Universal Location Framework. Proceedings of the 5th IEEE Workshop on Mobile Computing Systems \& Applications (WMCSA 2003), Monterey, CA, USA, October, pp. 122-128.

[71] Ko, Y., \& Vaidya, N. H. (2000). Location-aided routing (LAR) in mobile ad hoc networks. Wireless Networks, 6(4), 307-321.

[72] Liao, W.-H., Tseng, Y.-C., \& Sheu, J.-P. (2001). GRID: a fully location-aware routing protocol for mobile ad hoc networks. Telecommunication Systems, 18(1), 37-60.

[73] Kuhn, F., Wattenhofer, R., Zhang, Y., \& Zollinger, A. (2003). Geometric ad-hoc routing: of theory and practice. In Proceedings of the ACM (PODC'03) (pp. 63-72).

[74] Jiang, X., \& Camp, T. (2002). Review of geocasting protocols for a mobile ad hoc network. In Proceedings of the Grace Hopper Celebration (GHC).

[75] Ko, Y. \& Vaidya, N. H. (1999). Geocasting in mobile ad hoc networks: location-based multicast algorithms. In Proceedings of the IEEE (WMCSA'99) (pp. 101).

[76] Mauve, M., Fuler, H., Widmer, J., \& Lang, T. (2003). Position-based multicast routing for mobile ad-hoc networks (Technical Report TR-03-004). Department of Computer Science, University of Mannheim.

[77] Xu, Y., Heidemann, J., \& Estrin, D. (2001). Geographyinformed energy conservation for adhoc routing. In Proceedings of the ACM/IEEE (MOBICOM'01) (pp. 70-84).

[78] Hu, Y.-C., Perrig, A., \& Johnson, D. (2003). Packet leashes: a defense against wormhole attacks in wireless ad hoc networks. In Proceedings of the INFOCOM' 03 (pp. 19761986).

[79] Patwari, N., Hero III, A. O., Perkins, M., Correal, N. S., \& O'Dea, R. J. (2003). Relative location estimation in wireless sensor networks. IEEE Transactions on Signal Processing, 51(8), 2137-2148.

[80] Baldauf, M., Dustdar, S., \& Rosenberg, F. (2007). A Survey on Context Aware Systems. International Journal of Ad Hoc and Ubiquitous Computing, Inderscience Publishers. forthcoming. Pre-print from: http://www.vitalab.tuwien.ac.at/ florian/papers/ijahuc2007.pdf

[81] Hong, D., Chiu, D.K.W., \& Shen, V.Y. (2005). Requirements elicitation for the design of context-aware applications in a ubiquitous environment. In Proceedings of ICEC'05 (pp. 590-596).

[82] Neeraj Tantubay, Dinesh Ratan Gautam and Mukesh Kumar
Dhariwal, A Review of Power Conservation in Wireless Mobile Ad hoc Network (MANET)", International Journal of computer Science Issues, Vol 8, Issue 4, No 1, July 2011

[83] Wenrui Zhao, Mostafa Ammar and Ellen Zegura, "A Message Ferrying Approach for Data Delivery in Sparse Mobile Ad Hoc Networks", MobiHoc'04, May 24-26, 2004, Roppongi, Japan.

[84] Sgroi et al., "Designing Wireless Protocols: Methodology and Applications, February 2000.

[85] Gyula et al., "Simulation-based optimization of communication protocols for large-scale wireless sensor networks", 10 October 2002

[86] Rao and Sharma, "Cross Layer Protocols For Multimedia Transmission in Wireless Networks", June 2012

[87] Herms et al, "Realism in Design and Evaluation of Wireless Routing Protocols", 2007.

About Author (s):

Associate Professor Nawaz Mohamudally works at University of Technology, Mauritius (UTM) and has undertaken supervision of MPhil/PhD Students for many years.

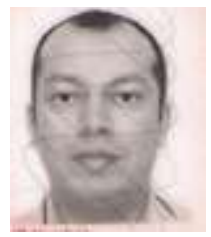

M. Kaleem Galamali is a part-time student (achieved M Phil Transfer on 28.10.2014, currently $\mathrm{PhD}$ student) at UTM under supervision of A.P. Nawaz Mohamudally. 